\title{
Sig mig, *hva' som* jeg skal gøre med sætningsskemaet: \\ De indledende pladser i nudanske indirekte spørgesætninger
}

\section{Alexandra R. Kratschmer \& Henrik Jørgensen}

\begin{abstract}
This paper discusses the structure of indirect question clauses in Danish. The construction is well-described in the literature, at least as far as the norm language is concerned. However, there is quite an amount of variation in certain syntactic contexts. Some of these have been touched upon in the literature, but not all. The interesting point concerning indirect question clauses in Danish is that their structure seems to be opaque even to language users normally associated with norm-obedience or even norm-setting. When clues like interpunctuation and vicarious subjects are considered, the structure of such sentences seems comparable to the structures of the other Mainland Scandinavian languages, Norwegian and Swedish.
\end{abstract}

\section{Nøgleord}

dansk, indirekte spørgesætninger, subjektsvikarer, standard, sprogbrug, kommatering

\section{Indledning}

I denne artikel diskuterer vi strukturen i indirekte spørgesætninger i dansk. Konstruktionen er sådan set klar nok og velbeskrevet i litteraturen, hvad det normerede standardsprog angår, sml. Retskrivningsregler §50, 6a. Der florerer en hel del ikke-normerede varianter i nogle bestemte syntaktiske kontekster; en del af disse er konstruktioner beskrevet i litteraturen, men ikke 
alle. Når de indirekte spørgesætninger interesserer os, skyldes det, at deres finesser tydeligvis ikke er bevidste for den type "gode og sikre sprogbrugere", som sprogreguleringen normalt tager hensyn til (sml. Bekendtgørelse om Dansk Sprognævns virksomhed og sammensætning, \$1 stk. 4). Tværtimod synes den danske befolkning - og navnlig blomsten af den opvoksende ungdom på universiteterne - gennem kommatering og forskellige andre variationsfænomener at vise, at den opfattelse af de syntaktiske forhold, som normeringen forudsætter, ikke er standard for dem. Gennem en analyse af de tæt beslægtede fastlandsskandinaviske nabosprog viser vi, at området er struktureret ganske anderledes i dem, og at den ikke-normerede sprogbrug i forskellige henseender er tættere beslægtet med situationen i svensk og norsk.

\section{Indirekte spørgesætninger: definition}

Indirekte spørgesætninger er ekspletive ledsætninger (kompletivsætninger) semantisk afhængige af verber ( $\mathrm{x}$ vide), substantiver ( $\mathrm{x}$ anelse) og adjektiver (fx nysgerrig). Disse ord tillader alle semantisk-logisk, at der indsættes en variabel i form af et spørgeord (hv-ord: hvad, hvem, hvordan) eller en spørgende konstruktion (hvilken bog) for en informationsenhed ${ }^{1}$, som ikke er givet i den umiddelbare kontekst, fordi den enten efterlyses, markeres som ukendt eller tilbageholdes. Prototypiske styrende elementer for efterlysning er spørgeverber (sporge, efterlyse) og imperativ af talehandlingsverber (fx sig (mig)), mens intentionelle perceptionsverber (se efter, lytte efter), udtryk for verificering (kontrollere, verificere, tjekke, slå fast) og udtryk for videbegær (vare nysgerrig, gerne ville vide) markerer efterlysning i bredere forstand. Markering som ukendt foretages ved hjælp af udtryk for usikkerhed og ikke-viden (ikke vare sikker, ikke vide), udtryk for glemsel (glemme, ikke huske) og, i bredere forstand, verber for skøn og gæt (skønne, gette). Tilbageholdelse af information styres af udtryk for viden (vide, huske, vare klar over), verber for afsløring (afsløre, sige, indrømme), verber/udtryk for opdagelse, bevidstgørelse (blive klar over, opdage), ikke-intentionelle perceptionsverber (se, høre), samt generelt ytrings- og meningsverber (sige; bifalde). ${ }^{2} \mathrm{Vi}$ bruger navnet 'indirekte spørgesætning' for alle disse kontekster, da vores ærinde i denne sammenhæng er rent syntaktisk

1 Konjunktionerne om og hvorvidt er ikke relevante i denne sammenhæng, da de indleder indirekte helspørgsmål.

2 For en lignende, bred behandling af indirekte spørgesætninger, se fx Bach og Schmitt Jensen (1990: 538-541) vedr. italiensk. 
og ikke pragmatisk, og da variablen, der erstatter informationsenheden i ledsætningen, er spørgende af form.

Eksemplerne (1) (semantisk afhængigt af verbet) og (3) (semantisk afhængigt af adjektivet) viser begge efterlysning af information, mens eksemplet 2 (semantisk afhængigt af verbalsubstantivet) viser mangel på information.

(1) Jeg vil gerne vide, hvem der kommer.

(2) Jeg har ingen anelse om, hvem der kommer.

(3) Jeg er nysgerrig efter, hvem der kommer.

Følgende tre eksempler viser tilbageholdelse af informationsenheden; ledsætningerne er her semantisk afhængige af hhv. et verbum (4), et substantiv (5) og et adjektiv (6).

(4) Jeg ved, hvem der kommer.

(5) Jeg har en anelse om, hvem der kommer.

(6) Jeg er klar over, hvem der kommer.

\section{Der og som: diakront}

Det regnes normalt for standard at bruge der efter spørgende pronominer som hvem, hvad og hvilket, når disse repræsenterer subjektet i ledsætningen:

(7) Læs hvilken kendis der lige nu har disse guldstøvler til salg på DBA (Den Blå Avis 2017)

(8) (...) hvor valget af hardware har betydning for hvilke LST-funktioner der kan stilles til rådighed (universitetsopgave 2019)

(9) Ved du, hvem der har været mester for dette puds? Mikkelsen 1911: 34)

(10) Jeg aner ikke hvad der har bevæget ham dertil. (smst.)

(11) Blot jeg vidste, hvilket parti der har vundet. (smst.)

(12) Det kommer an på, hvor stor en sum der bliver tilovers. (smst.)

Dog støder man hyppigt også på brug af som i stedet for der i disse kontekster:

(13) Baggrunden for notatet er, at flere undervisere har udtrykt tvivl om, hvilke regler som er gældende i bedømmelsessituationen for portolio [sic] og, da flere undervisere oplever uenighed med eksterne censorer på netop dette område. (Notat fra universitetsadministrationen) 
(14) At afgøre hvilke elementer som begrunder, og hvilke som begrundes, er aldrig blot en mekanisk øvelse - det involverer fortolkning. (Universitetslærebog)

(15) I vurderingen af hvilke elementer i en tekst som har argumentative funktioner som præmis eller konklusion, kan man nemlig bruge argumentmarkører som testinstrument. (Universitetslærebog)

Dette er på ingen måde et nyt fænomen. Mikkelsen (1911: 35) har citater fra det 18. og 19. århundrede med som i denne funktion:

(16) Nu seer jeg, hvad som har været Aarsag til min hastige Forandring (Holberg efter Mikkelsen (1911: 35))

(17) Hvad som forvolder dette, kan jeg ikke engang forklare. (Fru Gyllembourg efter Mikkelsen (1911: 35))

Hansen \& Heltoft (2011: 1636) giver en eksemplifikation fra 1600-tallet til i dag. De bemærker, at "[m]uligvis har afhængig spørgesætning med $h v$-led og som været en løbende mulighed i talesproget, fra reformationen til vore dage."

\section{Der og som: registerforskelle}

Det er interessant at bemærke, at formen med der i Aage Hansens Vort vanskelige sprog (1965: 177) er kodificeret som standard, og at indsættelsen af som på dette sted opfattes som "lavere sprog":

(18) Man har jo lov at gætte hvilken af 2 kategorier fra hans skibsværft som kunne løbe hurtigst (Tidens Kvinder 1962 efter Hansen 1965: 177)

(19) Disse tegninger (...) har givet mig et væsentligt indtryk af, hvilken forkyndelse, som taler til børn (Kristeligt Dagblad 1962 efter Hansen 1965: 177)

\section{Ikke-normeret som i ikke-subjektskontekster}

Som kan dog også findes i kontekster, hvor der ikke er fremrykket et subjekt, men et led af anden type. Denne konstruktion er helt uden for normeringen, og hvis den nævnes, er det kun i tilfælde, hvor man ønsker at advare mod 
den. Aage Hansen anfører et eksempel fra 1955, hvor det famøse som har sneget sig ind efter et objekt:

(20) Jeg overraskes ustandseligt over, hvilken mængde af menneskelighed i enhver henseende, af naturlighed (...) som dette folk har bevaret (overs. 1955 efter Hansen 1965: 177-178)

Som efter objekt findes ligeledes i nutidige kontekster:

(21) Begrundelsen for de enkelte forestillingers kulturelle succes og spredning er ikke afhængig af, hvilke særlige egenskaber hver forestilling har, men i stedet hvilken template, som den aktiverer (Studenteropgave, 2019)

(22) Så fortæl mig, hva' som jeg ska' gør' (fra sangteksten "Sig mig” af Citybois, 2019, https://genius.com/Citybois-sig-mig-lyrics)

(23) jeg har kun kigget på hvilke ting som X producerer (Mundtl. eksamen Nordisk 2019; kontekst: lydoptagelse børnesprog; formuleringer, som barnet gentager efter voksne, ikke medregnet i analysen (kun netop dem, barnet selv producerer)

(24) ... den fortæller mig hvilken signatur som en android den har (Mundtlig samtale, 2019; fortolket som relativsætning med ekstrapositionsled)

Der findes derudover nutidige kontekster med som efter efterlyst adverbial:

(25) hvordan som vi har det ... (underforstået "med hinanden, det er spørgsmålet"; fra Gift ved forste blik, sæson 2019, sendt 5. september 2019 på DR)

(26) Jeg foreslår ... Død \& Kridte, at Navnegruppen/Svend Rønnest (som ofte tilkendegiver sig her på sitet) eller hvem og hvordan som det nu måtte være, oprettede en tråd eller ligefrem en site, hvor alle Netfugls lyse hoveder kunne gå ind og FORESLÅ og ARGUMENTERE for respektive danske navn for pågældende art(er). (http://www. netfugl.dk/forum.php?id=thread\&forum_id=4\&thread_id=21133)

Og slutteligt kan vi finde kontekster med som efter en styrelse, hvis præpositional er strandet (Herslund 1984, Nguyen 2018): 
(27) Mange skoler ved ikke, hvilke tegn på mobning eller lignende, som de skal kigge efter. (Ekstra Bladet, 2019)

(28) På baggrund af respondenternes respons på CA-øvelsen kan forskeren så efterfølgende estimere, hvilke attributter for godet som respondenterne lægger relativt mest vægt på. (KorpusDK)

(29) T-huskeceller har til opgave, at gemme information om hvilke fremmede celler, som kroppen har været inficeret med. (KorpusDK) (30) og hvor vi hjælper den enkelte med at få afklaret hvilken efteruddannelse og hvilke kurser som det kan være relevant at søge tilskud til. (KorpusDK)

\section{Der og som: kommatering}

Kommatering volder som bekendt udfordringer, selv i det veluddannede befolkningssegment. Interessant nok er fejlagtig brug af komma i den indirekte spørgesætning foran der et relativt robust fænomen. ${ }^{3} \mathrm{Og}$ specielt hvis dette bringes i forbindelse med den allerede nævnte ikke-standardgrammatiske brug af som i stedet for der i disse sætninger (jeg vil gerne vide(,) hvilke studerende, som har afleveret synopsen), kunne det tyde på, at tegnsætningen følger brugernes opfattelse af disse kontekster som 'hovedsætningsrod indeholdende et direkte objekt (jeg vil gerne vide hvilke studerende)' plus 'relativsætning afhængig af substantivsyntagmekernen studerende (der/som har afleveret synopsen)', en analyse, som vi vil vende tilbage til.

Her følger (skriftlige) eksempler med der og forkert kommatering:

(31) (...) hvor valget af hardware har betydning for hvilke LST-funktioner, der kan stilles til rådighed. (Universitetsopgave, 2019)

(32) men da vi har med redigerede filmoptagelser at gøre, vil vi aldrig helt kunne vide hvor meget styring, der har været. (do.)

(33) Ved kategorisering af svarene i del to har jeg skitseret, hvilken talehandling, der primært bliver brugt i hver situation af hver målgruppe (do.)

3 Konstruktionen forekommer med eller uden komma foran det spørgende sætningsled: jeg vil gerne vide(,) hvilke studerende, $\boldsymbol{d e r}$ har afleveret synopsen). Blandt purister er betegnelsen "idiotkomma" for komma foran der i indirekte spørgesætninger gængs (Hårbøl 1993: 104, sml. DDO’s opslag 'idiotkomma'). 
(34) Et syn på, hvilken type talehandlinger, der bruges, medfører et bedre overblik over, hvilke høflighedsstrategier, bruges i konteksten, da bestemte talehandlinger kan fastslå, hvilken form for hensyn, taleren tager til modtagerens 'face' (do.)

Eksempler med som og forkert komma:

(35) Boyer fokuserer primært på, hvilken form for religion, som transmitteres bedst ... (Universitetsopgave, 2019)

(36) Og det er ham, der lægger taktikken og i dag skal meddele hvilke 11 , som skal starte på banen. (KorpusDK)

(37) Du putter en masse frø i jorden og ved ikke, hvilke af dem, som bliver til noget. (KorpusDK)

(38) For det andet, at der er enighed om, hvilke af disse regler, som skal være gældende. (KorpusDK)

(39) Vi ved jo ikke, hvilke af dyrenes egenskaber, som kan gå tabt i løbet af nogle generationer. (KorpusDK)

Flere af eksemplerne med som og præpositional stranding (27 og 29) har i øvrigt også forkert kommatering.

Forkert komma (markeret i det følgende med understregning) findes desuden i kontekster uden som eller der:

(40) Først må læseren være opmærksom [på] sin egen tænkning under læsning og vide hvilke kognitive processer, det kræver at forstå en bestemt tekst. (Universitetsopgave, 2019)

(41) I Det Centrale Personregister har vi samtidig indhentet oplysninger om, hvor mange børn under 18 år, du har. (SU-styrelsen, maj 2019)

Og kommateringen kan også være inkonsekvent inden for samme tekst:

(42) Først må læseren være opmærksom [på] sin egen tænkning under læsning og vide hvilke kognitive processer, det kræver at forstå en bestemt tekst. Herefter er det vigtigt løbende at kunne overvåge, hvad der er forstået og ikke forstået. Slutteligt må læseren vide, hvilke kompenserende strategier, ${ }_{2}$ der er nyttige at anvende, når der opstår problemer med forståelsen under læsningen (Baker \& Brown 1984:354). (Universitetsopgave, 2019) 
Yderligere inkonsekvens finder vi i denne kilde: Den Blå Avis, netudgave (https://guide.dba.dk/sjov/laes-hvilken-kendis-der-lige-nu-har-disse-guldstovler-til-salg-pa-dba), 22.9.2017). Eksempel (44) - med "idiotkomma" - er fra tekstens overskrift, mens eks. (45) - der er korrekt i forhold til normeringen - findes et meget kort stykke nede i teksten:

(43) Læs hvilken kendis, ${ }_{2}$ der lige nu har disse guldstøvler til salg på DBA

(44) Her kan du læse, hvilken kendis der har så stor en forkærlighed for genbrug.

Alt dette eksempelmateriale viser, at usikkerheden ikke kun optræder i subjektskontekster, men også i objektskontekster, adverbielle kontekster samt kontekster med præpositionalstranding, hvor det konsekvent er som, der optræder.

\section{Subjektsvikaren der i dansk grammatisk tradition}

Den hidtil rådende analyse af subjektsvikaren der (og dens alternativ her, som udelukkende anvendes i hovedsætninger) i dansk er egentlig opbygget af Kr. Mikkelsen (1911: §§ 13-18). Den videreføres af Paul Diderichsen (1962: § 69, anm. 2) og Erteschik-Shir (1984).

Analysen siger groft sagt, at overalt, hvor subjektspositionen er tom, overtages pladsen af der/her. Der er to forskellige konstruktioner, der medfører, at subjektspladsen er tom:

- Den første mulighed findes i alle sætningstyper: Subjektet anses for semantisk ubekendt for modtageren og står derfor på en anden plads i sætningskæden end subjektspositionen, typisk en objektsposition (Diderichsen 1962 §69 till. 2; Erteschik-Shir 1984: 133; Heltoft 1987).

- Den anden mulighed findes kun ved neutral ledfølge. Her kan subjektet være rykket frem på konjunktionalpositionen eller (i relativsætninger) stå i oversætningen. Dermed er subjektspositionen tom, og der kan indtage subjektspositionen (Diderichsen 1962 §69, till. 2; Erteschik-Shir 1984: 134). 
Eksempler på konstruktion I:

(45) Nu skal der laves pandekager

(46) Saa var der faldet en Sten ned fra Taget

(sml. Diderichsen 1962: 182)

Eksempler på konstruktion II:

(47) Vi vilde se, hvem der var højest (indirekte spørgesætning)

(48) Kusken, der anede Uraad, standsede Hestene (relativsætning) (sml. Diderichsen 1962: 183)

Ligheden mellem de to konstruktioner er, at subjektet i begge tilfælde er flyttet væk fra sin normale plads i syntaksen. På den anden side er der tre vigtige forskelle: Den ene er, at konstruktion I fungerer i begge sætningstyper (deklarativ og neutral rækkefølge), mens konstruktion II kun fungerer i neutral rækkefølge. Den anden er, at konstruktion I forudsætter, at subjektet er flyttet tilbage, mens konstruktion II forudsætter, at subjektet er flyttet frem eller befinder sig andetsteds. Endelig viser eksemplerne, at kun konstruktion II kan indledes af som; det forekommer aldrig ved konstruktion I.

Analysen af konstruktionerne I og II fra Mikkelsen og Diderichsen videreføres af de fleste nyere fremstillinger af dansk syntaks, inkl. Hansen \& Heltoft (2011: 304-306, 1213-1226; 1521-1522, 1593-1595). Konstellationen af $h v$-ord og der/som behandles forskellige steder, grundigst 1593-1595, 1635-1636 og 1670-1672. Kun konstruktioner med der regnes til normen; brugen af som regnes for at være "uden for rigsmålet", hvor 'rigsmålet' forstås som 'det sprog, som normerende instanser ville anbefale'. Hansen \& Heltoft peger på tendensen til brug af som i forbindelse med særlig omfangsrige $h v$-led (2011: 1670).

Trods de overfladiske paralleller mellem sætninger med der og sætninger med som er det nødvendigt at analysere de to konstruktioner forskelligt, sml. Hansen \& Heltoft (2011: 167 1; vores tilføjelser i [] og fremhævninger af som og der): 


\begin{tabular}{|l|l|l|l|l|}
\hline \multicolumn{2}{|l|}{ [Konjunktionalfelt] } & $\mathbf{A}^{\mathrm{m} 1}$ & $\begin{array}{l}\text { [Resten af } \\
\text { sætningen] }\end{array}$ \\
\hline Fokus & $\mathbf{M}^{\mathbf{1}}$ & & $\mathbf{M}^{\mathbf{2}}$ & Kerne \\
\hline $\begin{array}{l}\text { hvilken af } \\
\text { læsningerne }\end{array}$ & som & & $\begin{array}{l}\text { der er mest hold } \\
\text { i }\end{array}$ \\
\hline $\begin{array}{l}\text { hvilket } \\
\text { materiale... }\end{array}$ & som & & & de ønsker retur \\
\hline hvorfor & mon & så & at $^{4}$ & pengene er væk \\
\hline hvem af jer & som & & at & $\begin{array}{l}\text { der har stjålet } \\
\text { dem }\end{array}$ \\
\hline
\end{tabular}

Tabel 1: Position i satningsskema af som og der $i$ indirekte sporgesatninger ifolge Hansen $\mathbb{E}$ Heltoft (2011: 1671).

Opdelingen af konjunktionalfeltet i tabel 1 er lavet efter Hansen \& Heltoft 2011: 1589 og 1591. Kernen i konjunktionalfeltet er de to modalpladser $\left(\mathrm{M}^{1}\right.$ og $\left.\mathrm{M}^{2}\right)$, der indeholder hhv. den ydre og den indre konjunktion (sml. Hansen og Heltoft 2011: 1657-1669). Begge disse placeringer har potentielt tilknyttet adverbialpladser $\left(\mathrm{A}^{\mathrm{m} 1} \mathrm{og} \mathrm{A}^{\mathrm{m} 2}\right)$, hvoraf vi for overskuelighedens skyld kun medtager den første i skemaet. Desuden rummer konjunktionalfeltet en fokusplads helt til venstre.

I indirekte spørgesætninger befinder det spørgeformede element sig på selve konjunktionalfeltets fokusplads, som indtager $\mathrm{M}^{1}$ i konjunktionalfeltet, og der befinder sig inde i kernen på subjektspladsen.

I mange traditionelle grammatikker finder vi en beskrivelse af som og der som relative partikler (Hansen 1965: 177) eller sågar som relative pronominer ("henførende henvisningsord", Mikkelsen 1911: 291-292). Implicit ville denne identifikation medføre, at de to ord skulle stå på samme plads, mens det fremgår af skemaet ovenover, at den nugældende analyse (fra Diderichsen til Hansen \& Heltoft) afviser dette. Interessant nok synes sprogbrugerne dog også at lave identifikationen af som og der i henseende til funktion. Hansen \& Heltoft (2011: 1671) peger på de tilsyneladende analogier med relativkonstruktioner, især omkring de ikke-standardmæssige konstruktioner. Konstruktionerne bliver tilsyneladende opfattet af sprogbrugerne ud fra lokale mønstre uden hensyn til den globale syntaks.

Hansen \& Heltoft beskriver situationen (2011: 1670-1672) således: Hvleddet behandles af sprogbrugerne som et fællesled, og resten af sætningen

4 Forekomsten af at på M2 er det 'indre at', sml. Hansen \& Heltoft (2011: 1160). 
fortolkes som en (præsupponeret) relativsætning, der er knyttet hertil. Vi sætter for tydelighedens skyld eksemplerne ind i en tabel:

\begin{tabular}{|l|l|l|}
\hline Oversætning & "Fællesled" & "Relativsætning" \\
\hline Ansøgere bør have at vide & hvilket materiale & $\begin{array}{l}\text { som udvalget har fundet } \\
\text { relevant }\end{array}$ \\
\hline
\end{tabular}

Tabel 2: Sprogbrugernes tilsyneladende analyse af en indirekte sporgesetning som fallesled plus relativsetning (den indirekte sporgesetning er semantisk styret af et verbum $i$ oversatningen).

I dette tilfælde viser konstruktionen sig som anakolutisk, idet verbet vide normalt ikke tager nominalt objekt, kun sætningsformet objekt. Vi generaliserer denne analyse til eksemplerne med substantiv og adjektiv som semantisk styrende:

\begin{tabular}{|l|l|l|}
\hline Oversætning & "Fællesled" & "Relativsætning" \\
\hline Jeg har ingen anelse om & hvem & der (/som) kommer \\
\hline Jeg er nysgerrig efter & hvem & der (/som) kommer \\
\hline
\end{tabular}

Tabel 3: Sprogbrugernes tilsyneladende analyse af indirekte sporgesetninger som fallesled plus relativsatning (de indirekte sporgesetninger er semantisk styret af hhv. et substantiv og et adjektiv $i$ oversatningen).

Den sidste del af konstruktionen bliver altså opfattet som et sammenhængende lokalt mønster, men det betinger, at den første del af konstruktionen ikke længere giver en kohærent mening, da det er tydeligt, at den overordnede syntaktiske sammenhængs valenskrav ikke bliver opfyldt i disse konstruktioner. Det er også interessant, at en nærmest anakolutisk konstruktion udvikler sig til 'hvad vi plejer at gøre'. Selv om konstruktionen næppe kan analyseres anderledes, end at den er anakolutisk, ser det ud til, at den efterhånden ikke opleves sådan. ${ }^{5}$ En analyse af de prosodiske forhold omkring disse konstruktioner ville være relevant, men falder uden for rammerne af denne fremstilling.

5 Den hyppigt forekommende forkerte kommatering i kontekster som jo flere, der kommer... synes at vise, at forekomsten af et der udløser en re-analyse af den lokale kontekst som en relativsætning, uanset hvilke anakolutier der ellers optræder, hvilket igen viser, at dette fænomen er meget mere generelt end i de indirekte spørgesætninger (tak til Jan Heegaard for observationen). 
Det kunne også se ud, som om relativsætningerne kan blive påvirket af de typiske konstruktioner fra indirekte spørgesætninger, sml. dette tilfælde, hvor der forekommer et sted, hvor standardsproget ikke forudser det:

(49) [når du bager,] være [sic!] ikke bange for at benytte grøntsager, hvis smage der kan komplementere det søde (studenteropgave 2019) ${ }^{6}$

\section{Et blik på søstersprogene: svensk og norsk}

Svensk og norsk anvender andre markører end dansk for funktion I og II. Som foreløbigt subjekt anvendes det (med enkelte eksotiske imitationer af danske mønstre i norsk som undtagelse, sml. Western (1921: 263)). I ledsætninger anvendes som efter spørgeord.

Svensk anvender altid som på subjektspladsen efter andre konjunktionaler, sml. Thorell (1973: 236).

(50) Tag reda på vilken dag som är lämplig (Thorell)

(51) Människorna i familjer med hund bör därför ha ordentliga kunskaper om vilka livsmedel som kan skada vovven. (https://www.zooplus. se/magasin/hund/hundutfodring/vad-far-hunden-inte-ata/)

(52) Det är inte känt vad som exakt gör att vindruvorna är giftiga för hunden. (https://www.modernadjurforsakringar.se/tips-och-rad/ vad-far-hundar-inte-ata/)

Angående norsk analyseres som ifølge Askedal (1986: 29) i dette tilfælde som placeret på subjektspladsen, analogt med analysen af der (kstr. II) i dansk.

(53) $\AA$ vite hva som skal skje i den nærmeste fremtid og hvordan det påvirker ditt liv. (https://www.waterlogic.no/blogg/betydningenav-trivsel-pa-arbeidsplassen/)

(54) Kun ved å øke kompetansen rundt hva som skaper trivsel på en arbeidsplass, er vi et skritt nærmere målet. (https://fagbloggen. fagakademiet.no/7-faktorer-som-er-viktige-for-a-oppna-trivsel-pajobben)

6 Dette er dog muligvis en generalisering af nogle gængse ikke-standardkonstruktioner:

(i) ... en virus som der har spredt sig meget hurtigere end ventet

(ii) ... en hund som der har fået lopper igen-igen, og som der ikke er til at komme af med

Tak til Lars Heltoft for at gøre os opmærksomme på denne mulighed 
(55) Her får du vite hva som skjer på Aker Brygge. (https://www. akerbrygge.no/hva-skjer/)

(56) Dersom du ønsker å holde deg oppdatert om hva som skjer i Oslo Spektrum, kan du melde deg på vårt Nyhetsbrev, følge oss på Twitter og Facebook! (https://www.oslospektrum.no/arrangementer.133570.no.html)

Svensk og norsk opviser således en anden løsning på problemet end dansk.

- I tilfælde, hvor det element, der opfylder sætningens subjektsvalens, af semantisk-pragmatiske grunde ikke kan udfylde subjektspladsen, indsættes det.

- I tilfælde, hvor subjektet er et spørgeord i konjunktionalfeltet, anvendes som til at udfylde subjektspladsen.

\section{Et bud på en analyse af dansk efter svensk-norsk forbillede}

En tilsvarende analyse af dansk kunne se således ud:

- I tilfælde, hvor det element, der opfylder sætningens subjektsvalens, af semantisk-pragmatiske grunde ikke kan udfylde subjektsfunktionen, indsættes der.

- I tilfælde, hvor subjektet er et spørgeord i konjunktionalfeltet, anvendes enten der eller som (med en præference for der i traditionelt skriftsprog).

Som kan uden for traditionelt skriftsprog anvendes, hvor spørgeordet har en anden funktion end subjektsfunktionen i ledsætningen.

Disse analyser fastholder, at der er tale om subjektsvikarer i de indirekte ledsætninger. 


\begin{tabular}{|c|c|c|c|c|c|c|c|c|c|}
\hline \multicolumn{3}{|c|}{ Modalfelt } & \multicolumn{6}{|c|}{ Kernefelt } & \multirow{2}{*}{$\begin{array}{l}\begin{array}{l}\text { Lokalise- } \\
\text { ringsfelt }\end{array} \\
\text { FA }\end{array}$} \\
\hline Fokus & M1 & M2 & $\mathbf{S}$ & $\mathbf{A} 1$ & $\mathbf{V}$ & IO-DO & A3 & P-MV & \\
\hline hvem & & (at) & der & & $\begin{array}{l}\text { er kom- } \\
\text { met }\end{array}$ & & & & \\
\hline hvem & som & (at) & & & $\begin{array}{l}\text { er kom- } \\
\text { met }\end{array}$ & & & & \\
\hline hvad & & (at) & jeg & & skal gøre & & & & \\
\hline hvad & som & (at) & jeg & & skal gøre & & & & \\
\hline
\end{tabular}

Tabel 4: Position $i$ satningsskemaet af der og som $i$ nudanske indirekte sporgesatninger.

Dette er nøje parallelt med relativsætningerne. Vi indsætter følgende sætninger: "[Hvem er den mand] der er kommet", "[Hvem er den mand] som er kommet" og "[Hvem er den mand] (som) du har hilst på." og "hvis smage der kan komplementere det søde".

\begin{tabular}{|l|l|l|l|l|l|l|l|l|l|}
\hline \multicolumn{9}{|l|}{ Modalfelt } & \multicolumn{3}{|l|}{ Kernefelt } & $\begin{array}{l}\text { Lokalise- } \\
\text { ringsfelt }\end{array}$ \\
\hline Fokus & M1 & M2 & S & A1 & V & IO-DO & A3 & P-MV & FA \\
\hline & som & (at) & der & & $\begin{array}{l}\text { er kom- } \\
\text { met }\end{array}$ & & & & \\
\hline & (som) & (at) & du & & $\begin{array}{l}\text { er kom- } \\
\text { met }\end{array}$ & & & & \\
\hline har hilst & & der & & $\begin{array}{l}\text { kan } \\
\text { kom- } \\
\text { plemen- } \\
\text { tere }\end{array}$ & $\begin{array}{l}\text { det } \\
\text { søde }\end{array}$ & & & på & \\
\hline smage & & & and & & & & & & \\
\hline
\end{tabular}

Tabel 5: Position $i$ setningsskemaet af der og som $i$ nudanske relativsetninger.

\section{Konklusion}

I sprogbrugen anvendes som ganske hyppigt i indirekte spørgesætninger; den standardsproglige præference for der i denne sætningstype ser ud til at være i stærk konkurrence med som. Som bemærket af Hansen \& Heltoft kan vi ikke vide, om den standardsproglige der-norm nogensinde har haft greb om befolkningen i sin helhed. 
Som dukker op på steder, hvor der i henhold til normen ikke ville forekomme. Som forekommer i tilfælde, hvor spørgeordet er ikke-subjekt, og hvor standardsproget ikke har noget indskudselement i den pågældende konstruktion, fx når spørgeordet er direkte objekt, styrelse eller adverbial.

Det ser ud, som om sprogbrugerne foretager en re-analyse, hvor spørgeelementet fortolkes som korrelat, og resten af sætningen opfattes som en relativsætning knyttet hertil. Spørgeelementets status i forhold til den indlejrende syntaks er i denne "folkesyntaktiske" analyse helt uklar.

Det er formentlig nødvendigt at adskille brugen af som og der i deklarativ ordstilling fra brugen i neutral ordstilling. Det er to forskellige typer, og det er også to forskellige sæt markører. I deklarativ ordstilling finder vi kun der, men i neutral ordstilling både som og der. Valget mellem der og som i neutral ordstilling ville formodentlig have været frit, hvis det ikke havde været for sprognormeringen.

\section{Om forfatterne}

Alexandra Regina Kratschmer, lektor, Institut for Kommunikation og Kultur, Aarhus Universitet.

Henrik Jørgensen, lektor, Institut for Kommunikation og Kultur, Aarhus Universitet.

\section{Litteratur}

Askedal, J. O. (1986): Topologisk feltanalyse, koderingssystemer og pragmatiske funksjoner. En kontrastiv fremstilling på grunnlag av norsk, tysk, japansk og russisk. NyS 16-17, 18-55. https://www.nys.dk/article/ view/13341/11363 (lokaliseret 15.9.2019).

Bach, S. \& J. Schmitt Jensen (1990): Større italiensk grammatik. København: Munksgaard.

Dansk Sprognævn. Retskrivning. § 45-51. Komma. https://dsn.dk/retskrivning/retskrivningsregler/a7-40-60/a7-45-51 (lokaliseret 2.9.2019).

Diderichsen, P. (1946): Elementer dansk Grammatik. København: Gyldendal. Den danske ordbog. https://ordnet.dk/ddo (lokaliseret 24. 1. 2020).

Erteschik-Shir, N. (1984): Der. Nordic Journal of Linguistics 8, 131-148.

Hansen, E. \& L. Heltoft (2011): Grammatik over det danske sprog. Odense/ København: Syddansk Universitetsforlag/Det Danske Sprog- og Litteraturselskab.

Hansen, Aa. (1965): Vort vanskelige sprog. 2. udgave. København: Grafisk Forlag. 
Herslund. M. (1984): Particles, Prefixes and Prepositional Stranding. Nydanske Studier 14, 34-71.

Hårbøl, K. (1993): Kommaer i praksis - den grammatiske kommatering i nogle bøger og aviser. I Nyt fra Sprognaunet 1993/4. H. G. Jacobsen \& M. Gradenwitz (red.). København: Dansk Sprognævn \& Dansklærerforeningen, 89-123.

Mikkelsen, Kr. (1911): Dansk Ordföjningslere. Købenavn: Lehmann og Stage.

Nguyen. M. H. (2018): Om præpositionsstranding i dansk. Language Works - Sprogvidenskabeligt Studentertidsskrift 3/1, 62-89.

Thorell, O. (1973): Svensk Grammatik. Stockholm: Esselte Studium.

Vikner, St. (1991): Relative der and other Co elements in Danish. Lingua 84, 109-136.

Western, A. (1921). Norsk riksmåls-grammatikk for studerende og lerere. Kristiania: Aschehoug.

\section{Internetkilder}

Aker Brygge, Bydel Oslo. https://www.akerbrygge.no/ (lokaliseret 24.1.2020).

Citybois. 2019. Sig mig. Sangtekst (udgivelsesdato: 8. februar 2019). https:// genius.com/Citybois-sig-mig-lyrics (lokaliseret 5.4.2020).

Den Blå Avis. https://www.dba.dk/ (lokaliseret 23.3.2019).

Ekstrabladet. https://ekstrabladet.dk/ (lokaliseret 3.10.2019).

KorpusDK. https://ordnet.dk/korpusdk (lokaliseret 10.10.2019).

Moderna Djurförsäkringar. https://www.modernadjurforsakringar.se/ (lokaliseret 24.1.2020).

Netfugl. https://www.netfugl.dk/ (lokaliseret 24.1.2020).

Oslo Spektrum. https://www.oslospektrum.no/ (lokaliseret 24.1.2020).

Waterlogic Norge. https://www.waterlogic.no/ (lokaliseret 24.1.2020).

Aarhus Universitet. Administration. https://www.au.dk/ (lokaliseret 16.5.2020).

zooplus AG Sweden. https://www.zooplus.se/ (lokaliseret 24.1.2020). 